\title{
Characterization of the Cottonwood Grove and Ridgely Faults Near Reelfoot Lake,Tennessee, from High-Resolution Seismic Reflection Data
}

U.S. GEOLOGICAL SURVEY PROFESSIONAL PAPER 1538-I

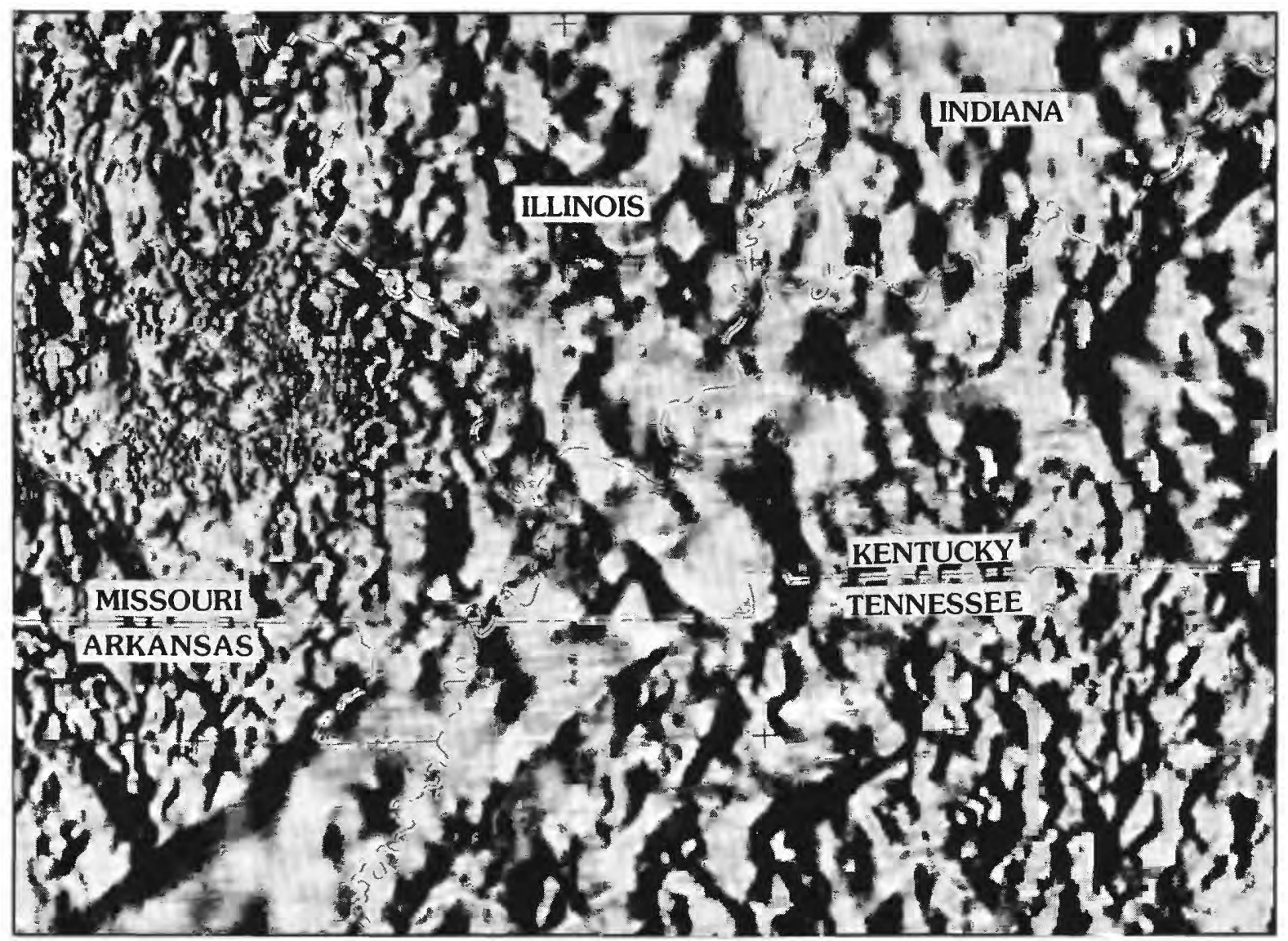


Cover. Gray, shaded-relief map of magnetic anomaly data. Map area includes parts of Missouri, Illinois, Indiana, Kentucky, Tennessee, and Arkansas. Illumination is from the west. Figure is from Geophysical setting of the Reelfoot rift and relations between rift structures and the New Madrid seismic zone, by Thomas G. Hildenbrand and John D. Hendricks (chapter $\mathrm{E}$ in this series). 


\section{Characterization of the Cottonwood Grove and Ridgely Faults Near Reelfoot Lake, Tennessee, from High-Resolution Seismic Reflection Data}

By William J. Stephenson, Kaye M. Shedlock, and Jack K. Odum

INVESTIGATIONS OF THE NEW MADRID SEISMIC ZONE

Edited by Kaye M. Shedlock and Arch C. Johnston

U.S. GEOLOGICAL SURVEY PROFESSIONAL PAPER 1538-I

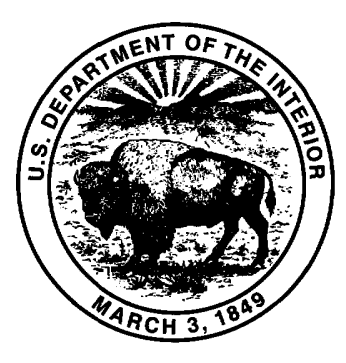

UNITED STATES GOVERNMENT PRINTING OFFICE, WASHINGTON : 1995 


\title{
U.S. DEPARTMENT OF THE INTERIOR \\ BRUCE BABBITT, Secretary
}

\author{
U.S. GEOLOGICAL SURVEY \\ Gordon P. Eaton, Director
}

For sale by U.S. Geological Survey, Information Services Box 25286, Federal Center

Denver, CO 80225

\begin{abstract}
Any use of trade, product, or firm names in this publication is for descriptive purposes only and does not imply endorsement by the U.S. Government
\end{abstract}

\section{Library of Congress Cataloging-in-Publication Data}

Stephenson, William J.

Characterization of the Cottonwood Grove and Ridgely faults near Reelfoot Lake, Tennessee, from high-resolution seismic reflection data / by William J. Stephenson, Kaye M. Shedlock, and Jack K. Odum.

p. cm.-(Investigations of the New Madrid seismic zone : I)

(U.S. Geological Survey professional paper : 1538)

Includes bibliographical references.

Supt.. of Docs. no. : I19.16: 1538I

1. Faults (Geology)-Tennessee-Reelfoot Lake Region. 2. Seismic reflection method. I. Shedlock, Kaye M. II. Odum, Jack K. III. Title. IV. Series.

V. Series: U.S. Geological Survey professional paper : 1538

QE535.2.U6I59 1995 vol. I

[QE606.5.U6]

$2^{\prime} 2^{\prime} 09778985 \mathrm{~s}-\mathrm{dc} 20$

[551.8'7'0976812] 


\section{CONTENTS}

Abstract.

\section{FIGURES}

1. Map of Reelfoot Lake area, Tennessee .....

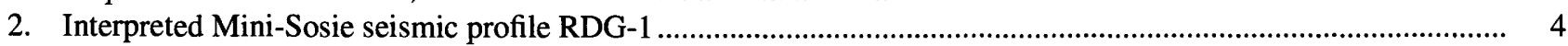

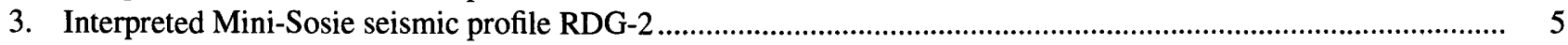

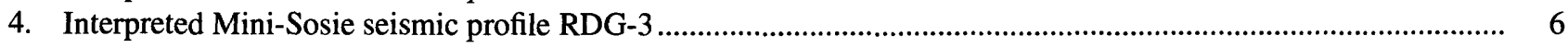

5. Map of faults imaged in high-resolution seismic reflection data .................................................................. 7

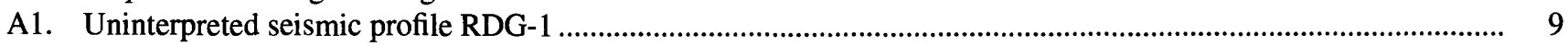

A2. Uninterpreted seismic profile RDG-2 ......................................................................................................

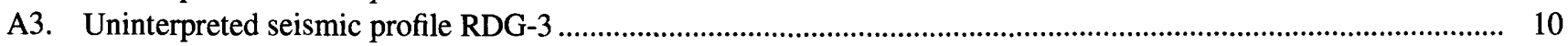

\section{TABLES}

1. Generalized Mini-Sosie data-acquisition parameters

2. Generalized processing steps used on Mini-Sosie seismic reflection data 



\title{
CHARACTERIZATION OF THE COTTONWOOD GROVE AND RIDGELY FAULTS NEAR REELFOOT LAKE, TENNESSEE, FROM HIGH-RESOLUTION SEISMIC REFLECTION DATA
}

\author{
By William J. Stephenson, ${ }^{1}$ Kaye M. Shedlock, ${ }^{1}$ and Jack K. Odum ${ }^{1}$
}

\begin{abstract}
High-resolution seismic reflection data acquired 2-10 $\mathrm{km}$ south of Reelfoot Lake, Tennessee, more clearly delineate the Cottonwood Grove and Ridgely faults as well as reveal a new, potentially major, fault with approximately 40 $\mathrm{m}$ of apparent vertical displacement, which is located east of the Ridgely fault. This new fault trends northwest, opposite in trend direction to the Cottonwood Grove and Ridgely faults, and dips vertically. The northeast-trending Cottonwood Grove fault has as much as $30 \mathrm{~m}$ of apparent vertical displacement on all imaged strata, from the Cretaceous/Paleozoic boundary to the middle Eocene horizon. This displacement suggests that faulting began post-middle Eocene. The northeast-trending Ridgely fault appears to be a zone of several fault strands bounding a horst-like structure. Apparent vertical displacements on strata across the easternmost strand of the Ridgely fault suggest recurrent displacement, with roughly $22-26 \mathrm{~m}$ of apparent offset on the Cretaceous/Paleozoic boundary and 18-22 m of apparent offset on middle Eocene deposits. The Quaternary/Eocene boundary was not sufficiently imaged on any seismic profile to determine if faulting has occurred later than post-middle Eocene.
\end{abstract}

${ }^{1}$ U.S. Geological Survey, Mail Stop 966, P.O. Box 25046, Denver Federal Center, Denver, CO 80225.

\section{INTRODUCTION}

The area surrounding Reelfoot Lake, Tennessee, is important for understanding the seismotectonics of the Mississippi Embayment-this is because the Reelfoot Lake area is a region of major historic and current seismicity in the New Madrid seismic zone (Stauder, 1982; Johnston and Shedlock, 1992) and because it has identifiable surface features related to recent faulting (less than 2,000 years old; Russ, 1982). The Lake County uplift, west of Reelfoot Lake (fig. 1), is an irregularly shaped topographic feature with as much as $10 \mathrm{~m}$ of topographic relief above the general level of the Mississippi River valley (Russ, 1982; Kelson and others, 1992). As described by Stearns (1979), the Lake County uplift contains numerous physiographic bulges. One of the most prominent of these is Ridgely ridge (fig. 1), rising $5 \mathrm{~m}$ above the level of the river valley. Vibroseis data acquired south of Reelfoot Lake resulted in the identification of the Cottonwood Grove and Ridgely faults (Zoback, 1979; Hamilton and Zoback, 1982), which are coincident with Ridgely ridge and possibly related to its uplift.

Using Vibroseis and Mini-Sosie seismic data, Zoback and others (1980) and Sexton and Jones (1986) inferred the displacement of middle Eocene deposits across the Cottonwood Grove fault (fig. 1). Shedlock and Harding (1982) further delineated the Cottonwood Grove fault, which crosses the Mississippi River $5 \mathrm{~km}$ southeast of Caruthersville, Mo., from seismic data collected along the Mississippi River. These studies suggested that the apparent vertical displacement on the Cottonwood Grove fault diminishes to both the northeast and the southwest. The Ridgely fault (fig. 1) essentially has been inferred from well data and has only 


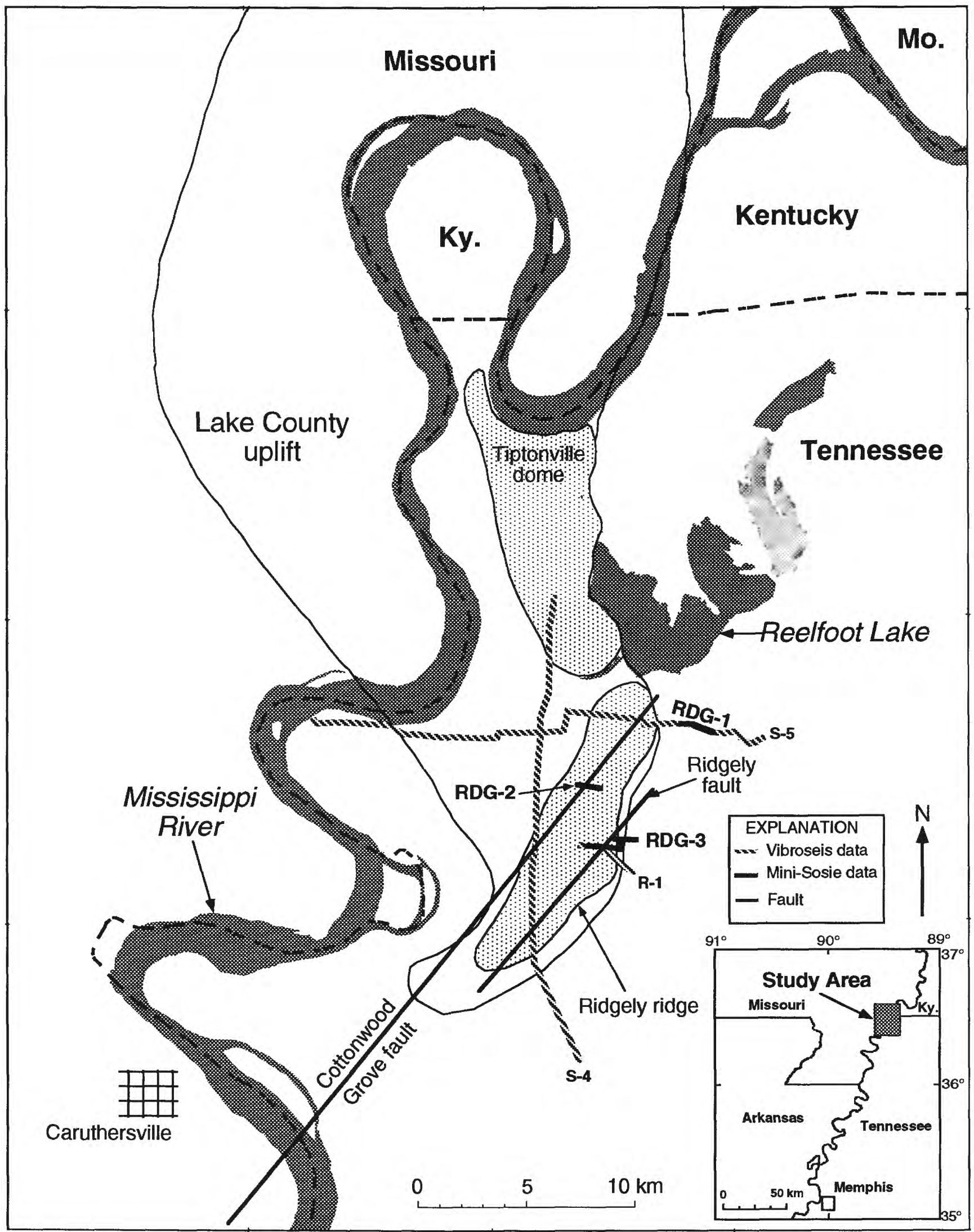


Figure 1 (facing page). Study area with seismic profiles and surficial features shown. Geomorphic features possibly related to faulting include the Tiptonville dome, Ridgely ridge, and the Lake County uplift. Seismic profile locations include Mini-Sosie lines RDG-1, RDG-2, and RDG-3 and Vibroseis lines S-4, S-5, and R-1. Surface locations of the Cottonwood Grove and Ridgely faults are based on projections from seismic reflection data (Zoback and others, 1980; Shedlock and Harding, 1982).

been observed in seismic data by Zoback (1979) and Zoback and others (1980).

We acquired three high-resolution Mini-Sosie seismic reflection profiles (fig. 1) across the northeastern Cottonwood Grove and Ridgely faults near Reelfoot Lake, Tennessee, (1) to better constrain their location and apparent vertical displacements, (2) to better characterize the faults and their faulting history, and (3) to map additional structures associated with these faults.

\section{SEISMIC INTERPRETATION AND ANALYSIS}

Data acquired with the Mini-Sosie method have been well-documented throughout the Mississippi Embayment (Sexton and Jones, 1986; Luzietti and others, 1992; VanArsdale and others, 1992; Odum and others, in press). This seismic acquisition method and its application are discussed by Wiles (1979) and Barbier (1983).

The data presented here were recorded with $28-\mathrm{Hz}$ resonant-frequency, vertical-component geophones in a cluster array. All data were acquired using an end-on spread, a minimum receiver offset of $60 \mathrm{~m}, 15.24-\mathrm{m}$ group intervals, and 24 receivers per shot (acquisition parameters are shown in table 1). The majority of the signal bandwidth of these data is between 30 and $140 \mathrm{~Hz}$ ( 40 to $80 \mathrm{~Hz}$ dominant bandwidth). The generalized processing steps used on these data are shown in table 2. Processing was conventional with the possible exceptions of adaptive deconvolution and post-stack, $90^{\circ}$ finite-difference time migration (Yilmaz, 1987), which further enhanced data resolution.

Vertical resolution of the Mini-Sosie data acquired for this study varies from about $4.5 \mathrm{~m}$ at $100 \mathrm{~ms}$ two-way travel time (TWTT) to about $8 \mathrm{~m}$ at $600 \mathrm{~ms}$ TWTT. Spatial resolution, expressed as the first-Fresnel-zone radius (Yilmaz, 1987), is on the order of $30 \mathrm{~m}$ at $100 \mathrm{~ms}$ and $85 \mathrm{~m}$ at $600 \mathrm{~ms}$ TWTT, although migration increases the resolution to less than a Fresnel zone. Correlations of reflections to local and regional lithologic units are based on the studies of Zoback and others (1980), Sexton and Jones (1986), and Odum and others (in press). The horizons interpreted on each of the respective lines are the Quaternary/Eocene unconformity $(\mathrm{Q} / \mathrm{E})$, the top of the middle Eocene Memphis Sand $\left(\mathrm{T}_{\mathrm{ms}}\right)$,
Table 1. Generalized Mini-Sosie data-acquisition parameters.

[gp, group]

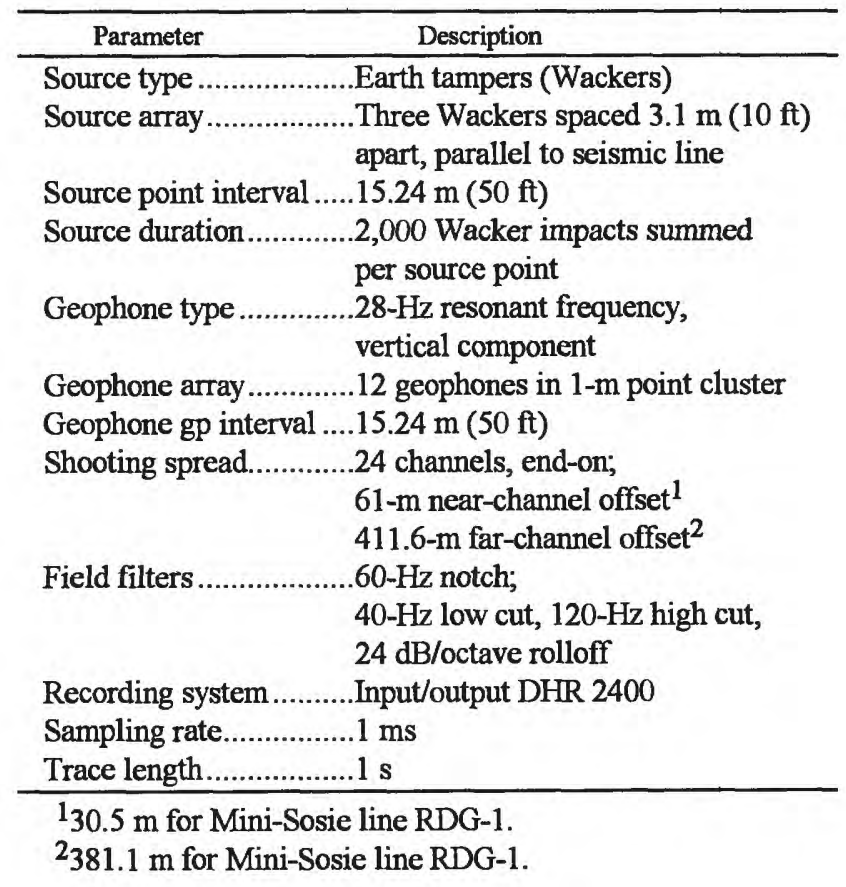

the top of the Paleocene Porters Creek Clay $\left(\mathrm{T}_{\mathrm{pc}}\right)$, and the Cretaceous/Paleozoic unconformity $\left(\mathrm{K} / \mathrm{P}_{\mathrm{z}}\right)$.

In addition to flexure of reflections, interpretations of faults in these data are often based on changes in frequency content across an interpreted structure as well as reflection terminations. All apparent vertical displacements estimated on each seismic profile are measured from the maximum to the minimum depth of a horizon across a given fault.

\section{MINI-SOSIE LINE RDG-1}

Mini-Sosie line RDG-1 was acquired across the (linear) surface projection of the Ridgely fault, over a section of U.S. Geological Survey (USGS) Vibroseis line S-5 of Hamilton and Zoback (1982), in an effort to identify any near-surface deformation possibly associated with this structure. Because the resolution of RDG-1 is higher than previously achieved with the Vibroseis data, the Mini-Sosie data successfully image reflectors into the middle Eocene $\left(\mathrm{T}_{\mathrm{ms}}\right)$ and permit a more detailed interpretation (fig. 2). Specifically, an upwarp observed on the Vibroseis data appears in the Mini-Sosie data to be a horst bounded by near-vertical fault strands that displace middle Eocene deposits (between stations 142 and 195). The fault splays bounding this horst probably represent the northeastern continuation of the Ridgely fault. The westernmost of these faults also apparently splays at around 400 ms TWTT. 
Table 2. Generalized processing steps used on Mini-Sosie high-resolution seismic reflection data, Ridgely, Tenn., area.

[AGC, automatic gain control; DMO, dip moveout; FK, frequency-wave number; Dyn, dynamic; FX, frequency-distance]

\begin{tabular}{|c|c|}
\hline Processing step & Parameters/comments \\
\hline \multicolumn{2}{|c|}{$\begin{array}{c}\text { Geometry ..................... Surface coordinates, elevations to } \\
\text { trace headers }\end{array}$} \\
\hline Trace edit... & $\begin{array}{l}\text { Bad traces removed from } \\
\text { processing }\end{array}$ \\
\hline AGC.. & $400 \mathrm{~ms}$ operator length \\
\hline Bandpass filter.. & $\begin{array}{l}\text { Zero-phase, } 25-40-140-170 \mathrm{~Hz} \\
(0 \%-100 \%-100 \%-0 \% \text { filter points }) \\
\text { pass band }\end{array}$ \\
\hline Resample........ & 2-ms sample rate \\
\hline \multicolumn{2}{|c|}{$\begin{array}{l}\text { Adaptive deconvolution... L2-norm spiking, } 200 \mathrm{~ms} \text { operator } \\
\text { length }\end{array}$} \\
\hline Trace muting..... & $\begin{array}{l}\text { Top mute (first arrivals) and bottom } \\
\text { mute (ground roll), 5-ms mute taper }\end{array}$ \\
\hline Elevation statics. & $1,000 \mathrm{~m} / \mathrm{s}$ weathered-layer velocity \\
\hline \multicolumn{2}{|c|}{$\begin{array}{l}\text { Normal moveout.......... Apply best velocity function of } \\
\text { as many as three determined from } \\
\text { constant velocity analysis }\end{array}$} \\
\hline Residual statics.. & $\begin{array}{l}\text { Apply best solutions of as many as } \\
\text { three surface-consistent passes; } \\
\text { 10-ms time shift allowed per pass }\end{array}$ \\
\hline DMO ................. & Common offset FK DMO \\
\hline Normal moveout. & $\begin{array}{l}\text { Remove pre-DMO normal moveout; } \\
\text { apply velocity function of post- } \\
\text { DMO analysis }\end{array}$ \\
\hline Stack... & Fold normalized \\
\hline Bandpass filter.. & $\begin{array}{l}\text { Zero-phase, } 25-40-140-170 \mathrm{~Hz} \\
(0 \%-100 \%-100 \%-0 \% \text { filter points }) \\
\text { pass band }\end{array}$ \\
\hline AGC .......... & $400 \mathrm{~ms}$ operator length \\
\hline $\begin{array}{l}\text { Dyn signal/noise } \\
\text { Migration............ }\end{array}$ & $\begin{array}{l}20-170 \mathrm{~Hz} \text { FX signal enhancement } \\
\text { Steep-dip finite-difference time } \\
\text { migration }\end{array}$ \\
\hline
\end{tabular}

Apparent vertical displacement across these two faults is estimated to be 20 to $26 \mathrm{~m}$ on all reflectors. The $T_{\mathrm{ms}}$ horizon has apparent vertical displacement of 20 to $21 \mathrm{~m}$ across both fault strands, whereas the $\mathrm{K} / \mathrm{P}_{\mathrm{z}}$ horizon has an apparent vertical displacement of 24 to $26 \mathrm{~m}$ across these strands. This suggests that fault movement has been recurrent (or episodic) on these structures since pre-middle Eocene time; however, the vertical resolution of these data is less than the differences in offset between the respective horizons, making this recurrence interpretation equivocal. The $T_{p c}$ horizon is poorly imaged on the eastern half of the line but has a faulted appearance at station 140 similar to the $\mathrm{T}_{\mathrm{ms}}$ and $\mathrm{K} / \mathrm{P}_{\mathrm{z}}$ horizons between stations 150 and 200 . Unfortunately, the Quaternary/Eocene boundary (interpreted at $125 \mathrm{~ms}$ TWTT between stations 100 and 130) was not successfully imaged across the horst; thus, any late-Eocene-to-Quaternary fault movement cannot be determined.

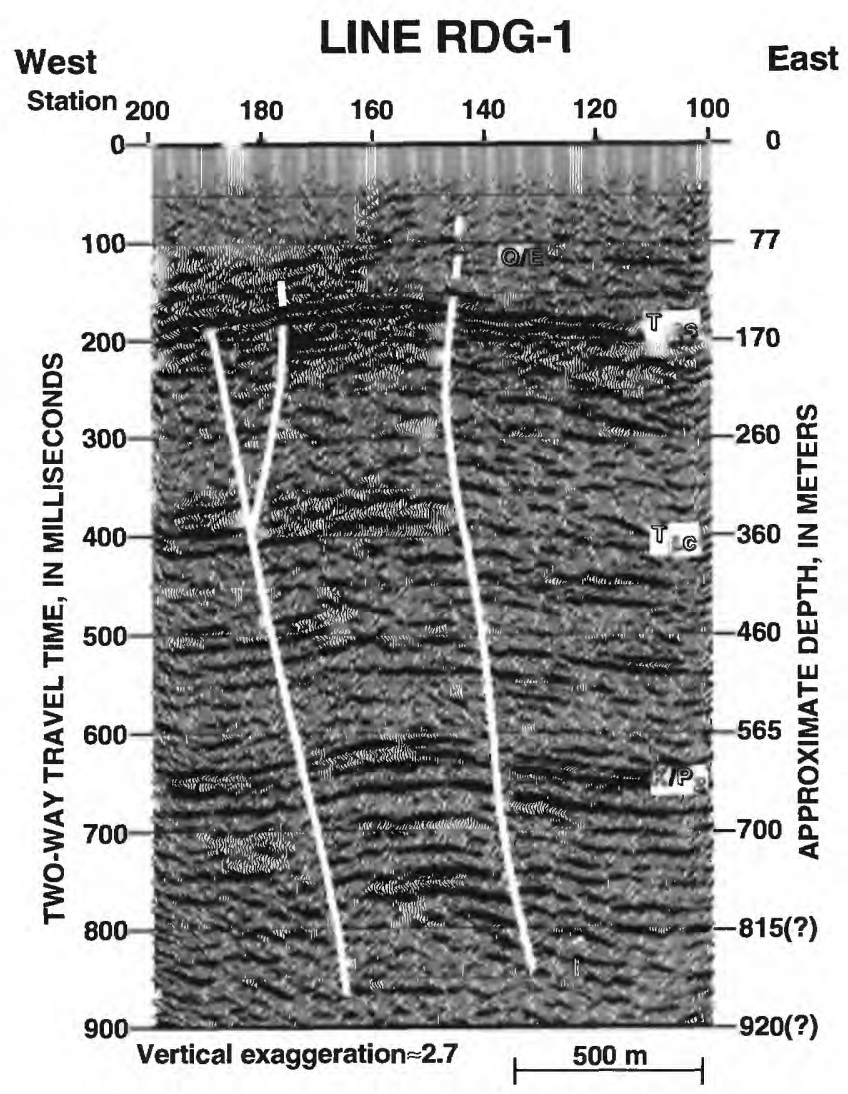

Figure 2. Mini-Sosie line RDG-1 reveals two fault strands bounding a horst beneath the surface projection of the Ridgely fault. The Quaternary/Eocene boundary $(\mathrm{Q} / \mathrm{E})$, the top of the middle Eocene Memphis Sand $\left(\mathrm{T}_{\mathrm{ms}}\right)$, the top of the Paleocene Porters Creek Clay $\left(\mathrm{T}_{\mathrm{pc}}\right)$, and the Cretaceous/Paleozoic boundary $\left(\mathrm{K} / \mathrm{P}_{\mathrm{z}}\right)$ are interpreted on the seismic profile. Deeper, approximate depths on the profile are queried because of poor seismic velocity control. Vertical exaggeration is estimated from an averaged, single stacking-velocity function. Uninterpreted section is shown in the Appendix as figure A1.

\section{MINI-SOSIE LINE RDG-2}

Mini-Sosie line RDG-2 was acquired along the linear projection of the Cottonwood Grove fault, as previously located with Vibroseis data (Hamilton and Zoback, 1982; Zoback and others, 1980). As seen in figure 3, our data indicate the fault intersects the $T_{m s}$ horizon $320 \mathrm{~m}$ west of the projected surface location as determined in previous Vibroseis studies. Apparent vertical displacements on both the interpreted $\mathrm{K} / \mathrm{P}_{\mathrm{z}}$ and $\mathrm{T}_{\mathrm{ms}}$ horizons are approximately 30 $\mathrm{m}$, suggesting fault activity has occurred since the middle Eocene. This interpretation is in general agreement with those of both Sexton and Jones (1988) and Zoback and others (1980), and our interpretation also supports the hypothesis that apparent vertical displacement on the Cottonwood Grove fault decreases to the northeast (Zoback and others, 1980). These data, like those of RDG-1, do not clearly resolve the Quaternary/Eocene boundary or Quaternary 


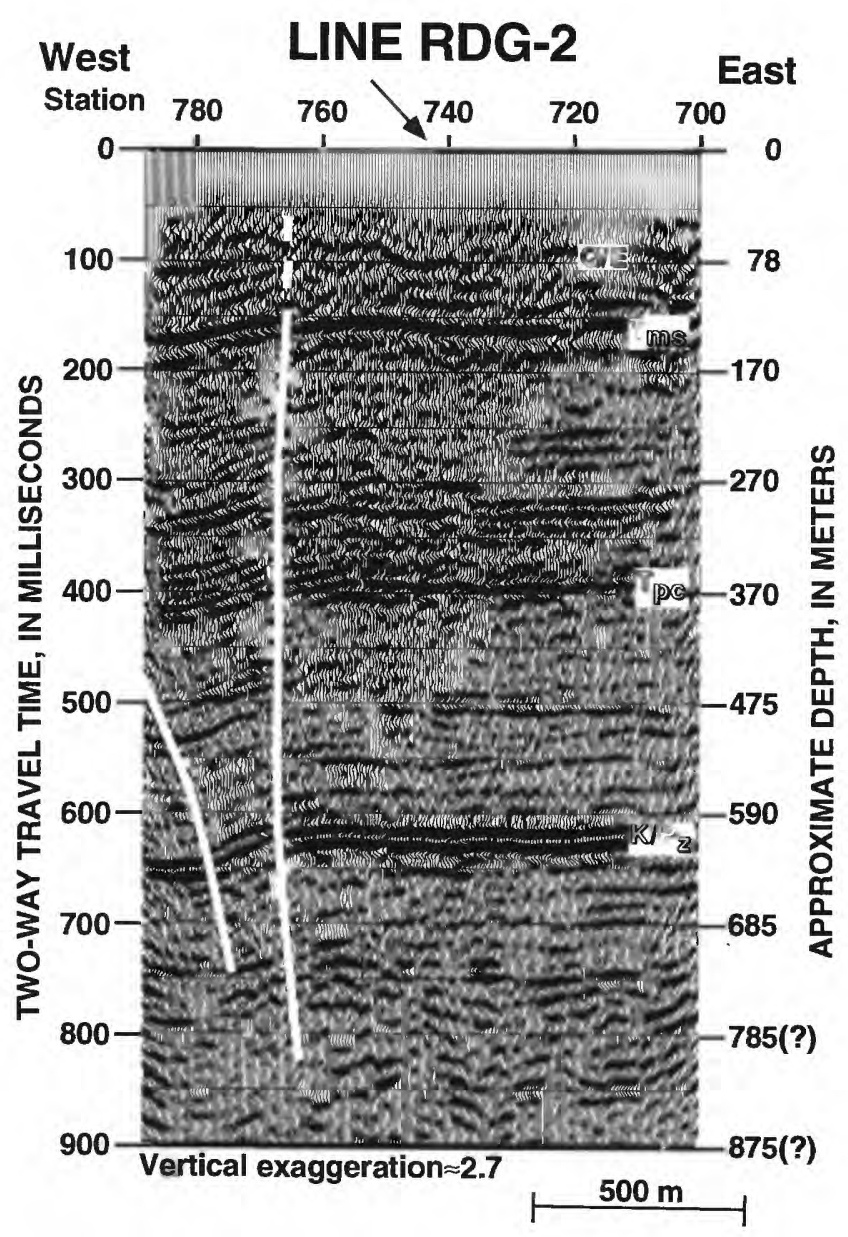

Figure 3. The Cottonwood Grove fault is imaged as two strands beneath Mini-Sosie line RDG-2. The location of the fault is approximately $320 \mathrm{~m}$ west of a linear surface projection (arrow) previously inferred from Vibroseis data. The Quaternary/Eocene boundary $(\mathrm{Q} / \mathrm{E})$, the top of the middle Eocene Memphis Sand $\left(\mathrm{T}_{\mathrm{ms}}\right)$, the top of the Paleocene Porters Creek Clay $\left(\mathrm{T}_{\mathrm{pc}}\right)$, and the Cretaceous/Paleozoic boundary $\left(\mathrm{K} / \mathrm{P}_{\mathrm{z}}\right)$ are interpreted on the seismic profile. Deeper, approximate depths on the profile are queried because of poor seismic velocity control. Vertical exaggeration is estimated from an averaged, single stacking-velocity function. Uninterpreted section is shown in the Appendix as figure A2.

units; hence, possible recurrent motion after the middle Eocene cannot be determined. A fault splay is apparent west of the interpreted main Cottonwood Grove fault, displacing the $\mathrm{K} / \mathrm{P}_{\mathrm{z}}$ horizon. No other faults were apparent in section RDG-2, as evidenced by the generally strong and continuous appearance of all reflections east of station 760. The disruption in the $T_{m s}$ reflection below station 720 is believed to be a stratigraphic feature, perhaps the edge of a paleochannel.

\section{MINI-SOSIE LINE RDG-3}

Mini-Sosie line RDG-3 consists of three, interconnected, two-dimensional Mini-Sosie lines merged into a single profile (figs. 1 and 4), with stations 210 to 260 positioned over a section of Vibroseis line R-1 (Zoback, 1979). The Mini-Sosie data reveal a much more complex subsurface fault system than had been previously inferred, with four faults interpreted. A horst between two near-vertical to steeply east dipping fault strands is apparent between stations 200 and 255. This structure had been previously imaged in Vibroseis data by Zoback (1979), and many of the reflections between 300 and $800 \mathrm{~ms}$ TWTT match well between the two data sets (although the reflector depths estimated by Zoback (1979) differ from those estimated in this study, which is probably a function of the different velocity functions calculated from the two data sets).

The apparent vertical displacement of the $\mathrm{K} / \mathrm{P}_{\mathrm{Z}}$ reflector across the horst is approximately $20 \mathrm{~m}$ on the eastern fault and $22 \mathrm{~m}$ on the western fault. The apparent vertical displacement of the $T_{\mathrm{ms}}$ reflector across both faults is about 18 $\mathrm{m}$. The $\mathrm{K} / \mathrm{P}_{\mathrm{z}}$ and $\mathrm{T}_{\mathrm{pc}}$ horizons dip gently eastward across the horst, suggesting rotation during faulting, whereas the $T_{m s}$ horizon appears primarily to be arched rather than rotated.

Between stations 155 and 180, RDG-3 changes direction from east-west to north-south. An apparent structure between stations 160 and 170 on the $\mathrm{K} / \mathrm{P}_{\mathrm{z}}$ horizon is most likely an out-of-plane reflection from the fault between stations 200 and 210; the reflection may be caused by the close proximity of this fault to the profile between stations 160 and 180. Evidence for this reflection being from out of the plane include the similar displacement on the $\mathrm{K} / \mathrm{P}_{\mathrm{z}}$ horizon and the lack of apparent displacement on the $T_{m s}$ horizon (the Fresnel zone is much smaller at $200 \mathrm{~ms}$ TWTT than at $650 \mathrm{~ms}$ TWTT; hence, the reflected wavelet did not sample as far laterally at shallow depth).

A third major, and previously unidentified, fault is imaged beneath station 120 on RDG-3. Approximately $40 \mathrm{~m}$ of apparent vertical displacement, down to the east, is observed on the $\mathrm{K} / \mathrm{P}_{\mathrm{z}}$ horizon. Apparent vertical displacement on the $T_{\text {ms }}$ horizon is approximately $11 \mathrm{~m}$, suggesting that vertical movement on this fault has been recurrent (or episodic) after formation of the $\mathrm{K} / \mathrm{P}_{\mathrm{z}}$ horizon and that faulting has occurred since the middle Eocene. This structure was not imaged on either Vibroseis line R-1 or on the north-south segment of line RDG-3.

We thus infer that the structural trend of this fault must be generally northwest-southeast because of its absence on Vibroseis line R-1 and the surficial geometric relationship between lines R-1 and RDG-3 (fig. 1). Interestingly, O'Connell and others (1982) interpreted a fault with the same sense of vertical displacement and with a surface projection (based on a focal mechanism) that trends at about $\mathrm{N}$. $20^{\circ} \mathrm{W}$., toward and roughly parallel to this third interpreted fault on line RDG-3. The relationship of this easternmost imaged fault to the surface projection of the fault plane as derived by O'Connell and others (1982) is shown in figure 5. 


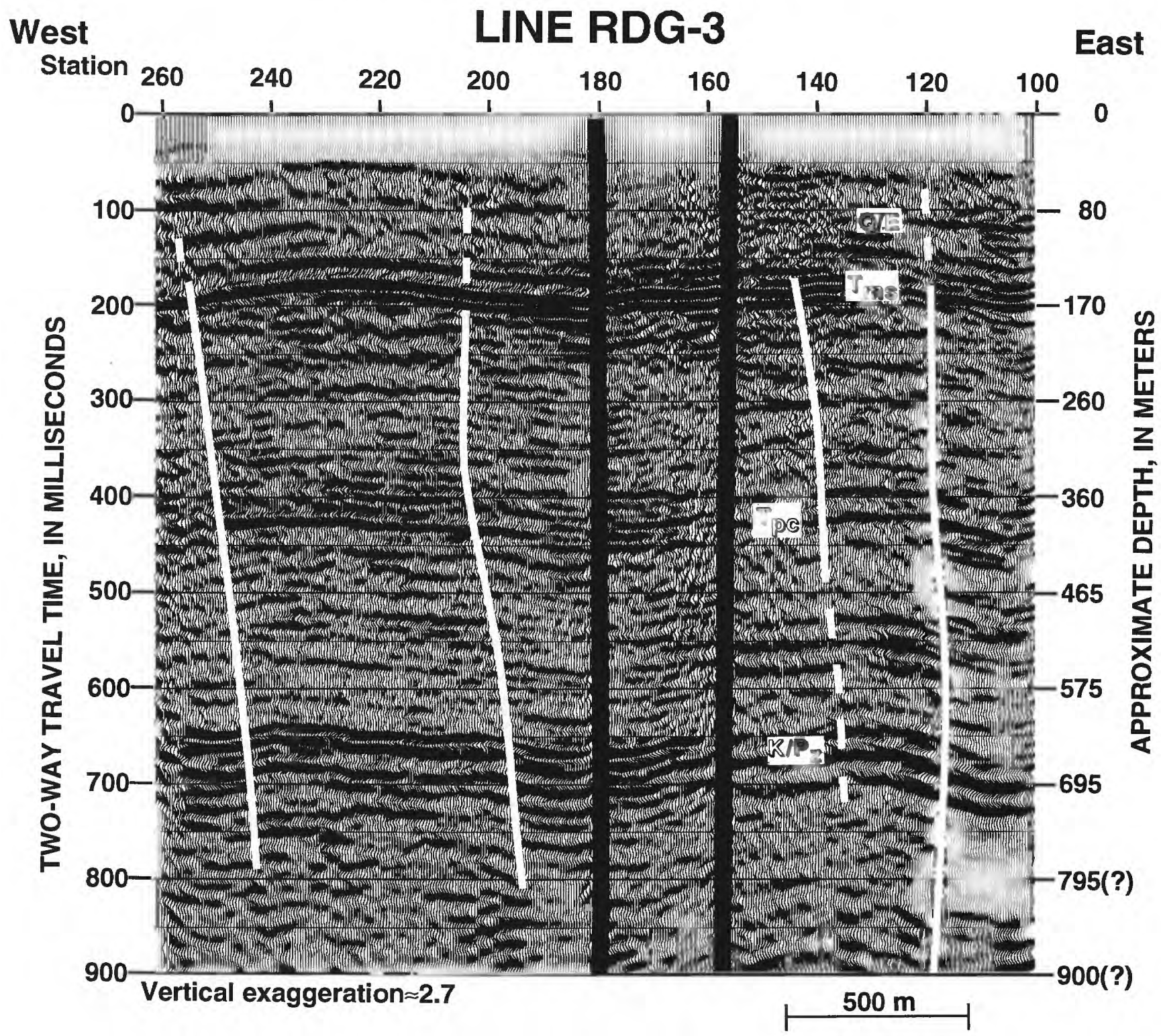

Figure 4. Four separate fault strands are interpreted on Mini-Sosie line RDG-3. The western two bound a horst that is probably also observed on RDG-1. The interpreted fault beneath station 145 has approximately $5 \mathrm{~m}$ of apparent vertical displacement. The easternmost fault is a previously unknown strand that has approximately $40 \mathrm{~m}$ of apparent vertical displacement across the $\mathrm{K} / \mathrm{P}_{\mathrm{Z}}$ horizon. The Quaternary/Eocene boundary $(\mathrm{Q} / \mathrm{E})$, the top of the middle Eocene Memphis Sand $\left(\mathrm{T}_{\mathrm{ms}}\right)$, the top of the Paleocene Porters Creek Clay ( $\left.\mathrm{T}_{\mathrm{pc}}\right)$, and the Cretaceous/Paleozoic boundary $\left(\mathrm{K}_{\mathrm{P}}\right)$ are interpreted on the seismic profile. Deeper, approximate depths on the profile are queried because of poor seismic velocity control. Vertical exaggeration is estimated from an averaged, single stacking-velocity function. Uninterpreted section is shown in the Appendix as figure A3. See text for explanation of heavy vertical lines.

\section{DISCUSSION}

We have purposefully used the phrase "apparent vertical displacement" to describe the fault offsets observed in these data because they could be caused by normal, thrust, strike-slip, or some combination of faulting. Strike-slip faulting can cause apparent vertical displacement when observed on a two-dimensional seismic profile because of bed dip and changes in bed thicknesses. Determining the type of faulting observed in these two-dimensional data is necessarily equivocal.

The interpreted faults are generally located on flexures in the reflections, even though some of the reflections may be continuous across an interpreted fault. This is acceptable 
in interpreting these data, as shown by the modeling of Mini-Sosie data acquired across the Cottonwood Grove fault (Sexton and Jones, 1986). The modeling results of Sexton and Jones (1986) indicated that, given the resolution of these data, the small relative displacements of fault strands across this fault system can yield flexed but fairly continuous reflections similar to those observed in our Mini-Sosie data. Essentially, the lateral smearing effects are caused by the relatively small apparent vertical fault displacements in relation to the Fresnel zone size. Alternately, it has been suggested that flexures of this type have the geometric characteristics of fault-bend folds (e.g., Suppe, 1983). Yet, until a cogent model is developed that can kinematically explain such features in this tectonic setting, we prefer to interpret the cause of these flexures as faults that have propagated into or through the respective horizons.

The horst structure observed on both lines RDG-1 and the western end of RDG- 3 correlates between the two lines and is interpreted to be the Ridgely fault (fig. 5). Previous studies did not project the Ridgely fault as far to the northeast, perhaps due to the lack of shallow, higher resolution information. The fault strands bounding the horst are interpreted to dip steeply to the southeast or are nearly vertical. If they do dip southeast, their relation to the southwest-dipping thrust plane determined from focal mechanisms (Chiu and others, 1992) is unclear.

\section{CONCLUSIONS}

Mini-Sosie lines RDG-1, RDG-2, and RDG-3 better delineate the Cottonwood Grove and Ridgely faults south of Reelfoot Lake (fig. 5) and indicate significant deformation as recently as post-middle Eocene on all imaged structures. Additionally, a previously unidentified fault with approximately $40 \mathrm{~m}$ of apparent vertical displacement on the Paleozoic surface, apparently trending to the northwest, was imaged east of the Ridgely fault. The Quaternary/Eocene boundary was not sufficiently imaged in either the Mini-Sosie or previously interpreted Vibroseis data (Hamilton and Zoback, 1982; Zoback and others, 1980) to determine if faulting has occurred later than post-middle Eocene in this area. Faulting does not appear to have been recurrent (or episodic) on the Cottonwood Grove fault. Conversely, apparent vertical displacements on strata across the Ridgely fault weakly suggest recurrence, with 22 to $26 \mathrm{~m}$ of apparent displacement of the $\mathrm{K} / \mathrm{P}_{\mathrm{Z}}$ boundary and 18 to $22 \mathrm{~m}$ on the $\mathrm{T}_{\mathrm{ms}}$ horizon. Vertical displacement does not appear to decrease to the northeast on the Ridgely fault, as is observed on the Cottonwood Grove fault.

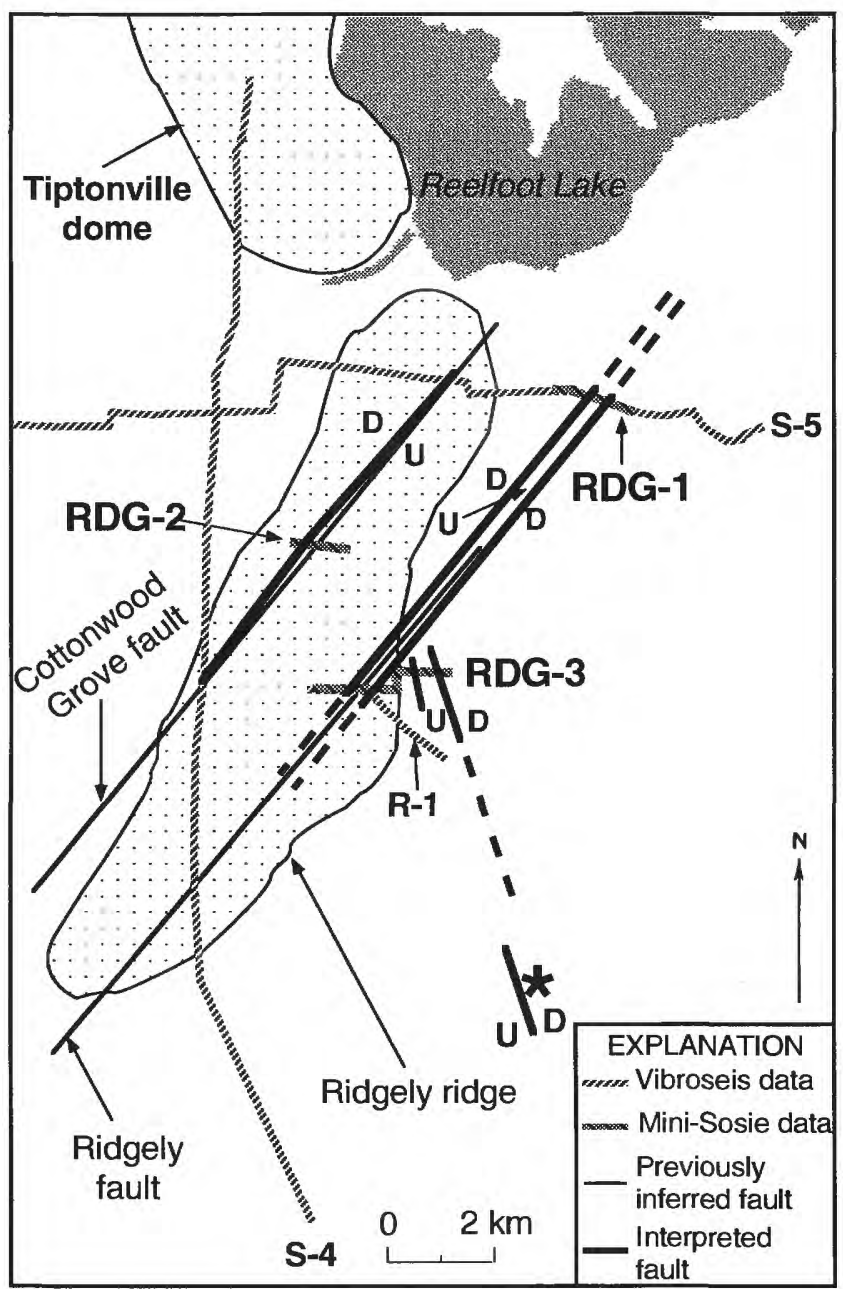

Figure 5. Surface projections (heavy black lines) of the Cottonwood Grove and Ridgely faults, inferred from this study. Locations of the Ridgely and Cottonwood Grove faults originally inferred from Vibroseis data are shown by thin lines. The Cottonwood Grove fault occurs very close to its previously inferred linear projection on line RDG-2. The Ridgely fault appears to continue northeast of its previously determined location (Zoback and others, 1980), across RDG-1. The surface projection of the fault plane from O'Connell and others (1982) is shown as a heavy line with an asterisk. D, downthrown side; $\mathrm{U}$, upthrown side.

\section{ACKNOWLEDGMENTS}

This work was supported by the U.S. Geological Survey through grants from the National Earthquake Hazards Reduction Program. The authors thank Dave Worley, John Michael, Rob Williams, Richard Dart, Susan Rhea, Dave Nicholas, Dave Kibler, Mike Ellis, Buddy Schweig, and students from the University of Arkansas and the University of Memphis for their efforts and support during data acquisition. 


\section{REFERENCES CITED}

Barbier, M.G., 1983, The Mini-Sosie Method: Boston, Mass., International Human Resources Development Corp., 86 p.

Chiu, J.M., Johnston, A.C., and Yang, Y.T., 1992, Imaging the active faults of the central New Madrid seismic zone using PANDA array data: Seismological Research Letters, v. 63, p. 375-393.

Hamilton, R.M., and Zoback, M.D., 1982, Tectonic features of the New Madrid seismic zone from seismic-reflection profiles: U.S. Geological Survey Professional Paper 1236-H, p. 55-81.

Johnston, A.C., and Shedlock, K.M., 1992, Overview of research in the New Madrid seismic zone: Seismological Research Letters, v. 63 , p. 193-208.

Kelson, K.I., VanArsdale, R.B., Simpson, G.D., and Lettis, W.R., 1992, Assessment of the style and timing of surficial deformation along the central Reelfoot scarp, Lake County, Tennessee: Seismological Research Letters, v. 63, p. 349-356.

Luzietti, E.A., Kanter, L.R., Schweig, E.S., Shedlock, K.M., and VanArsdale, R.B., 1992, Shallow deformation along the Crittenden County fault zone near the southeastern boundary of the Reelfoot rift, northeast Arkansas: Seismological Research Letters, v. 63, p. 263-276.

O'Connell, D.R.,. Bufe, C.G, and Zoback, M.D., 1982, Microearthquakes and faulting in the area of New Madrid, Missouri-Reelfoot Lake, Tennessee: U.S. Geological Survey Professional Paper 1236-H, p. 31-38.

Odum, J.K., Luzietti, E.A., Stephenson, W.J., Shedlock, K.M., and Michael, J.A., in press, High-resolution, shallow, seismic reflection surveys of the northwest Reelfoot rift boundary near Marston, Missouri, chap. P of Shedlock, K.M., and Johnston, A.C., Investigations of the New Madrid Seismic Zone: U.S. Geological Survey Professional Paper 1538-P.

Published in the Central Region, Denver, Colorado

Manuscript approved for publication December 20, 1994

Edited by Richard W. Scott, Jr.

Graphics prepared by Denny Welp, use made of author-drafted material

Photocomposition by Wayne Hawkins
Russ, D.P., 1982, Style and significance of surface deformation in the vicinity of New Madrid, Missouri: U.S. Geological Survey Professional Paper 1236-H, p. 95-114.

Sexton, J.L., and Jones, P.B., 1986, Evidence for recurrent faulting in the New Madrid seismic zone from Mini-Sosie high-resolution reflection data: Geophysics, v. 51, p. 1760-1788.

1988, Mini-Sosie high-resolution reflection survey of the Cottonwood Grove fault in northwestern Tennessee: Bulletin of the Seismological Society of America, v. 78, p. 838-854.

Shedlock, K.M., and Harding, S.T., 1982, Mississippi River seismic survey: Geophysical Research Letters, v. 9, p. 1275-1278.

Stauder, W., 1982, Present-day seismicity and identification of active faults in the New Madrid seismic zone: Seismological Research Letters, v. 63, p. 21-30.

Stearns, R.G., 1979, Recent vertical movement of the land surface in the Lake County uplift and Reelfoot Lake basin areas, Tennessee, Missouri, and Kentucky: U.S. Nuclear Regulatory Commission NUREG/CR-0874, p. 1-37.

Suppe, J., 1983, Geometry and kinematics of fault-bend folding: American Journal of Science, v. 283, p. 685-721.

VanArsdale, R.B., Schweig, E.S., Kanter, L.R., Williams, R.A., Shedlock, K.M., and King, K.W., 1992, Preliminary shallow seismic reflection survey of Crowley's Ridge, northeast Arkansas: Seismological Research Letters, v. 63, p. 309-320.

Wiles, C.J., 1979, Mini-Sosie: New concept in high-resolution seismic surveys: Oil and Gas Journal, v. 77, p. 94-97.

Yilmaz, O., 1987, Investigations in Geophysics No. 2: Seismic Data Processing: Tulsa, Okla., Society of Exploration Geophysicists, p. 507-518.

Zoback, M.D., 1979, Recurrent faulting in the vicinity of Reelfoot Lake, northwestern Tennessee: Geological Society of America Bulletin, v. 90, p. 1019-1024.

Zoback, M.D., Hamilton, R.M., Crone, A.J., Russ, D.P., McKeown, F.A., and Brockman, S.R., 1980, Recurrent intraplate tectonism in the New Madrid seismic zone: Science, v. 209, p. 971-976. 


\section{APPENDIX}

Three uninterpreted, high-resolution seismic reflection profiles acquired south of Reelfoot Lake, Tennessee.

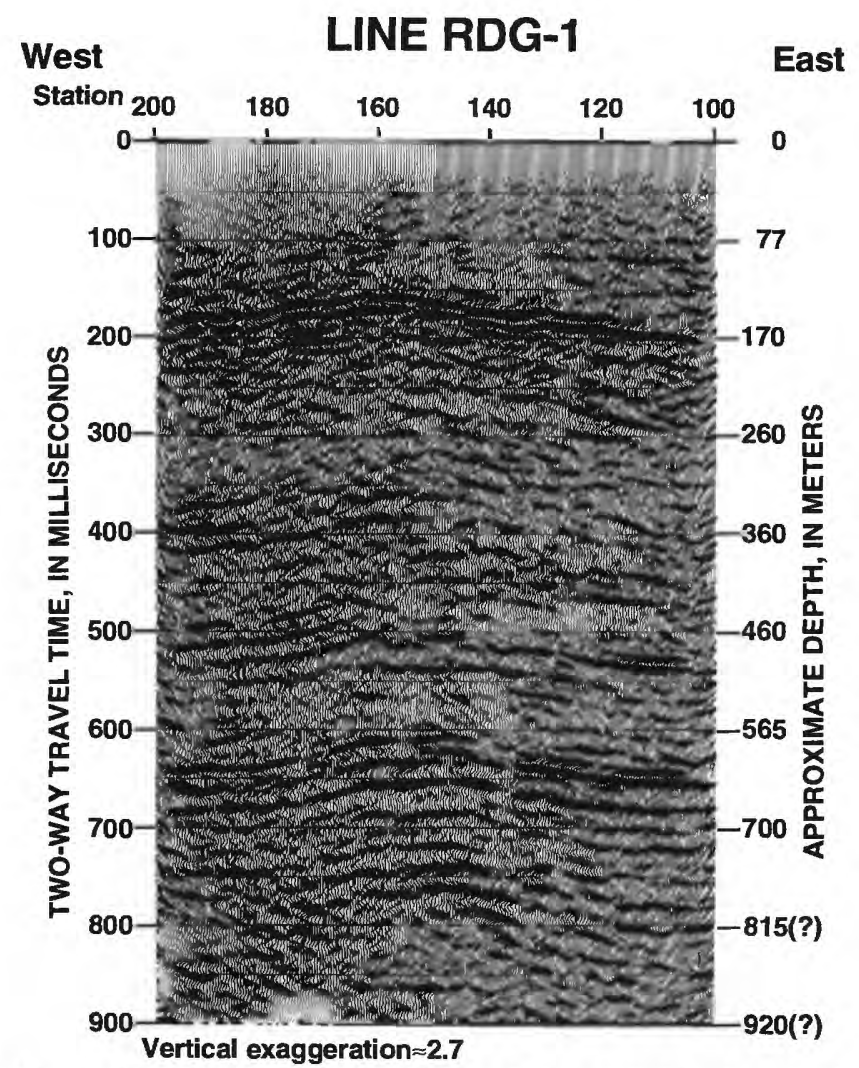

Figure A1. Uninterpreted, high-resolution, Mini-Sosie seismic reflection profile RDG-1.

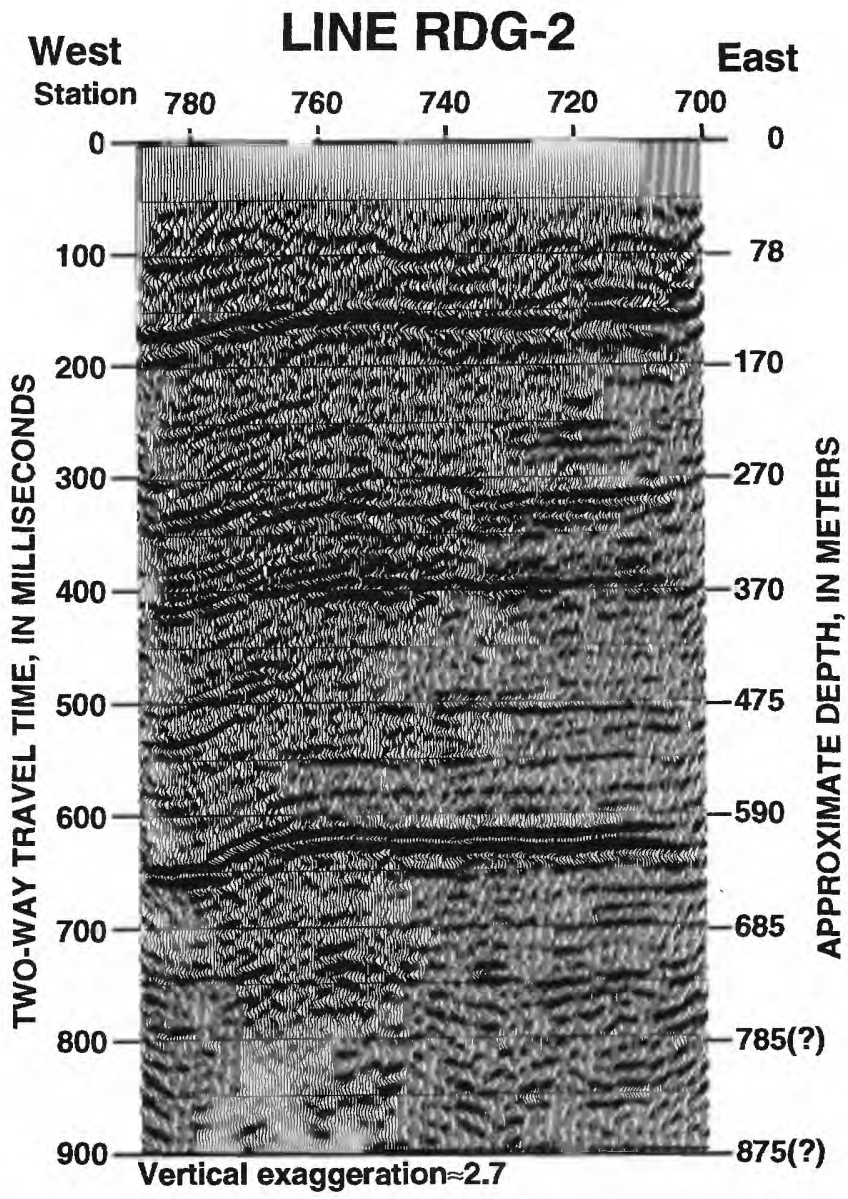

Figure A2. Uninterpreted, high-resolution, Mini-Sosie seismic reflection profile RDG-2. 


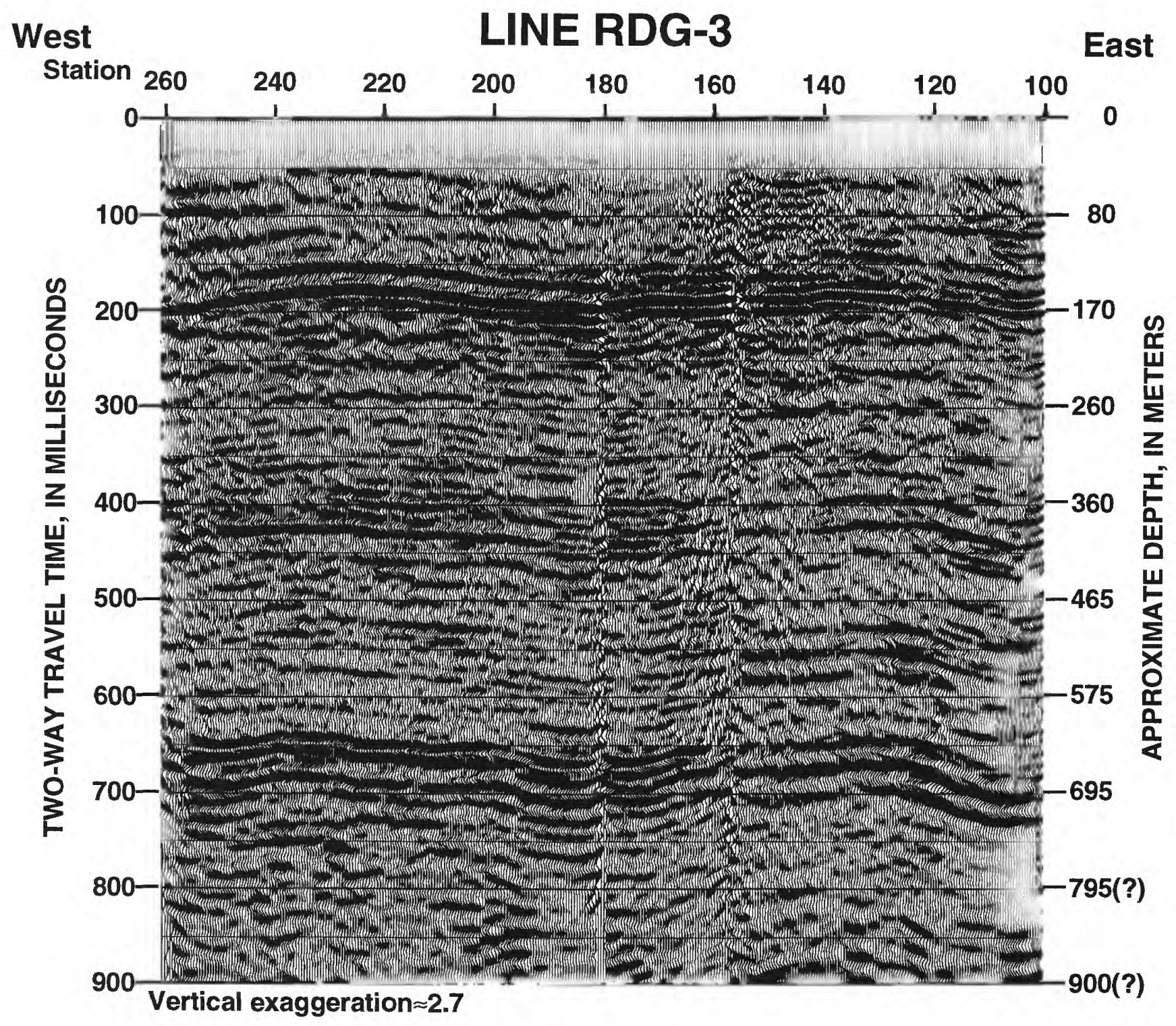

Figure A3. Uninterpreted, high-resolution, Mini-Sosie seismic reflection profile RDG-3. 